\title{
GEOGRAPHICAL READINGS
}

Climatic Geomorphology 
The Geographical Readings series

Published

Rivers and River Terraces G. H. DURY

Introduction to Coastline Development J. A. STEERS

Applied Coastal Geomorphology J. A. STEERS

World Vegetation Types S. R. EYRE

Developing the Underdeveloped Countries ALAN B. MOUNTJOY

Glaciers and Glacial Erosion CLIFFORD EMBLETON

Climatic Geomorphology EDWARD DERBYSHIRE

Transport and Development B. S. HOYLE

Other titles are in preparation 


\section{Climatic Geomorphology}

EDITED BY

EDWARD DERBYSHIRE

Macmillan Education 
ISBN 978-0-333-13653-9 ISBN 978-1-349-15508-8 (eBook)

DOI 10.1007/978-1-349-15508-8

Selection, editorial matter, translations and introduction

(C) Edward Derbyshire 1973

Softcover reprint of the hardcover 1st edition 1973 978-0-333-13652-2

All rights reserved. No part of this publication may be reproduced or transmitted, in any form or by any means, without permission

First published 1973 by THE MACMILLAN PRESS LTD

London and Basingstoke Associated companies in New York Toronto Melbourne Dublin Johannesburg and Madras

SBN 333136527 (hard cover) SBN 333136535 (paper cover)

The paperback edition of this book is sold subject to the condition that it shall not, by way of trade or otherwise, be lent, re-sold, hired out, or otherwise circulated without the publisher's prior consent in any form of binding or cover other than that in which it is published and without a similar condition including this condition being imposed on the subsequent purchaser 


\section{Contents}

ACKNOWLEDGEMENTS

INTRODUCTION 11

1 The Geographical Cycle BY William Morris Davis 19

2 Attempt at a Classification of Climate on a Physiographic Basis BY Albrecht Penck 51

3 Climate: Factor of Relief BY Emmanuel de Martonne 61

4 The Cycle of Glaciation BY William Herbert Hobbs 76

5 Morphology of Climatic Zones or Morphology of Landscape Belts? BY Siegfried Passarge 91

6 Landforms of the Savanna Zone with a Short Dry Season BY Franz Thorbecke $\quad 96$

7 The Climatic Geomorphic System BY Julius Büdel 104

8 The Geographic Cycle in Periglacial Regions as it is Related to Climatic Geomorphology BY Louis $C$. Peltier

9 The Problem of Erosion Surfaces, Cycles of Erosion and Climatic Geomorphology BY Herbert Louis

10 The Theory of Savanna Planation BY C. A. Cotton

11 An Alternate Approach to Morphogenetic Climates BY William F. Tanner

12 Area Sampling for Terrain Analysis By Louis $C$. Peltier

13 Climatogenetic Geomorphology By Julius Büdel 202

14 Morphogenic Systems and Morphoclimatic Regions BY Jean Tricart and André Cailleux

15 Relationships Between Geomorphic Processes and Modern Climates as a Method in Paleoclimatology BY Lee Wilson

Index 


\section{Acknowledgements}

The author and publishers wish to thank the following, who have kindly given permission for the use of copyright material

\section{Chapter 1}

The Geographical Cycle, by William Morris Davis, from Geographical Journal, 14 (1899) 481-504, by permission of the Royal Geographical Society

Glacial Erosion in France, Switzerland, and Norway, by William Morris Davis, from Proceedings Boston Society Natural History, 29 (1900) 273-322, by permission of Boston Society of Natural History The Geographical Cycle in an Arid Climate, by William Morris Davis, from Journal of Geology, 13 (1905) 381-407

\section{Chapter 2}

Versuch einer Klimaklassification auf physiographischer Grundlage, by Albrecht Penck, translated by Roger S. Mays, from Preussen Akademie der Wissenschaft Sitz. der physikalisch-mathematischen, Klasse 12 (1910) 236-246, by permission of Deutsche Akademie der Wissenschaften zu Berlin

\section{Chapter 3}

Le climat-facteur du relief, by Emmanuel de Martonne, translated by Edward Derbyshire, from Scientia (1913) 339-355, by permission of Masson and Company

\section{Chapter 4}

The Cycle of Mountain Glaciation, by William Herbert Hobbs, from Geographical Journal, 35 (1910) 146-163, by permission of the Royal Geographical Society

Studies of the Cycle of Glaciation, by William Herbert Hobbs, from Journal of Geology, 29 (1921) 370-386 


\section{Chapter 5}

Morphologie der Klimazonen oder Morphologie der Landschaftsgürtel?, by Siegfried Passarge, translated by Roger S. Mays and Edward Derbyshire, from Petermanns Geographische Mitteilungen, 72 (1926) 173-175, by permission of Haack Gotha

\section{Chapter 6}

Die Formenschatz im periodisch trocknen Tropenklima mit überwiegender Regenzeit, by Franz Thorbecke, translated by Roger S. Mays and Edward Derbyshire, from Düsseldorfer Geographische Vorträge und Erörterungen, 3 (1927) 10-17 by permission of Ferdinand Hirt Verlag and Frau Thorbecke

\section{Chapter 7}

Das System der Klimatischen Geomorphologie, by Julius Büdel, translated by Roger S. Mays, from Verhandl. Deutscher Geographie, 27 (1948) 65-100, by permission of the author

\section{Chapter 8}

The Geographic Cycle in Periglacial Regions as it is related to Climatic Geomorphology, by Louis C. Peltier, from the Annals of the Association of American Geographers, 40 (1950) 214-236, by permission of the Association of American Geographers

\section{Chapter 9}

Rumpfflächenproblem, Erosionszyklus und Klimamorphologie, by Herbert Louis, translated by Roger S. Mays from Geomorphologische Studien Hrsg. v. Herbert Louis u. Ing. Schaefer, 262 (1957) 9-26

\section{Chapter 10}

The Theory of Savanna Planation, by C. A. Cotton, from Geography, 46 (1961) 89-101, by permission of Geography

\section{Chapter 11}

An Alternate Approach to Morphogenetic Climates, by William F. Tanner, from Southeastern Geology, 2 (1961) 251-257, by permission of Southeastern Geology

Geomorphology and the Sediment Transport System, by William F. Tanner, from Southeastern Geology, 4 (1962) 113-126, by permission of Southeastern Geology 


\section{Chapter 12}

Area Sampling for Terrain Analysis, by Louis C. Peltier, from The Professional Geographer, 14 (1962), by permission of the Association of American Geographers

\section{Chapter 13}

Climatogenetic Geomorphology, by Julius Büdel, translated by Joyce M. Perry and Edward Derbyshire, from Geographische Rundschau, 15 (1963) 269-285

\section{Chapter 14}

Les grands ensembles morphoclimatiques naturels, chapters 3 and 5, from Introduction à la Géomorphologie Climatique, by Jean Tricart and André Cailleux, translated by Edward Derbyshire, by permission of the Longman Group Limited

\section{Chapter 15}

Les relations entre les processus géomorphologiques et le climat moderne comme méthode de paleoclimatologie, by Lee Wilson, from Revue de géographie physique et de géologie dynamique, 11 (1969) 303-314, by permission of Masson and Company

The publishers have made every effort to trace the copyrightholders but if they have inadvertently overlooked any, they will be pleased to make the necessary amendment at the first opportunity. 